\title{
A Study of Interlibrary Loan
}

From an examination of the data in several recent studies of interlibrary loans, an estimate of the present volume and general statements about interlibrary loan for all types of libraries in the United States can be made. Differences in interlibrary loan activity according to the type and size of library, the format, subject, recency, and language of material most requested, the success rate, time, and cost per transaction are noted.

A

Apart from our oaths, our threats, our tears and fears and resolutions and promises, apart from all of our emotional responses, what do we really know about interlibrary loan? Who borrows what from whom for what purposes? How good is the present system, and what is its future? The writer examined recent literature on interlibrary loan as part of a study of the feasibility of a national and of regionalized interlibrary loan centers made in 1972-73 for the Association of Research Libraries. ${ }^{1}$ What was most apparent in this examination was how little is known about interlibrary loan in the United States on any general scale. The most complete study was the doctoral dissertation of Sarah Thomson completed in 1968 at Columbia University, "General Interlibrary Loan Services in Major Academic Libraries in the United States."2 A more recent but less thorough survey was made for the Association of Research Libraries by the Westat Corporation: Vernon Palmour and others, A Study of the Characteristics, Costs, and Magnitude of Interlibrary Loans in Academic Libraries (1972). ${ }^{3}$ These are the only studies of nationwide

Mr. Stevens is professor of library science, Graduate School of Library Science, University of Illinois at Urbana-Champaign. interlibrary loan but are limited to loans by or to academic libraries.

Loans involving an academic library as lender or borrower or both have traditionally been thought to make up the major part of interlibrary loans. Several recent studies involving all types of libraries in a state or an interstate region have indicated, however, that academic loans are only a part of the picture and a small part at that. Studies of interlibrary loan within a state or interstate region vary from brief journal articles or studies of various cooperative services in the area, of which interlibrary loan is only a part, to full-scale studies of interlibrary loan services. The best examples of the latter are the several studies made by Nelson Associates, Inc., of NYSILL, the interlibrary loan system developed for New York State, and especially Interlibrary Loan in New York State. ${ }^{4}$ From an examination and comparison of the data provided by the two national studies and by several recent studies of state or regional areas, a number of generalizations can be made of the characteristics of interlibrary loan today. In this paper an attempt will be made to provide answers to the following: What types of libraries borrow most on interlibrary loan? What types are the principal lenders? What is the 
geography of interlibrary loan? What is the nature of the items borrowed? What degree of success in completion of interlibrary loan is usual? What is the average time necessary to complete loans? What is the cost to the lender, and what is the cost to the borrower? Finally, what changes in interlibrary loan may be expected in the near future?

Sarah Thomson reported 845,000 requests received by academic libraries in the United States in the year 1963/ $1964 .{ }^{5}$ By $1969 / 1970$ the number received by academic libraries had more than doubled, $1,750,000$, based on a sampling made by the Westat Corporation. ${ }^{6}$ No one knows what the total quantity of interlibrary loan requests handled by nonacademic libraries might be at the present time. The study of interlibrary loan in New York State indicated that less than 10 percent of the 644,000 requests from libraries of all types in New York State in 1968 were sent to college and university libraries in or outside of the state. This finding cannot be taken at face value, however, because it does not account for the loan requests handled by the state's large university libraries when functioning as part of regional networks or of NYSILL, the state's interlibrary loan system. ${ }^{7}$ Nevertheless, by a conservative estimate, the total quantity of interlibrary loan activity in the United States now could well be between six million and seven million requests per year.

\section{TyPES AND StZES OF LIBRARIES}

Which types of libraries originate most of these requests? In the Thomson study and in the study by Vernon Palmour and colleagues at Westat Research, Inc., it was shown that 75 percent and 60 percent, respectively, originate from academic libraries. ${ }^{8}$ Both of these studies, however, were restricted to academic libraries either as borrowers or lenders or both. The type of library requesting most titles after academic libraries in the Thomson and Palmour studies was the special library, from which 19 percent and 17 percent of the requests originated, while the public library initiated only 5 percent and 8 percent of the requests. A quite different order of types of libraries making most requests is provided in the New York State study. ${ }^{9}$ Of the 87,220 requests from all types of libraries in the state processed at the New York State Library in 1968 by NYSILL, 74 percent came from public libraries and 24 percent from academic libraries. Not included in this statistic were loans handled directly between libraries, without processing through NYSILL, whether inside or outside the state.

Some further information on the proportion of requests from the different types may be obtained from the study of the Bibliographic Center for Research, Rocky Mountain Region, by Casey, from two studies of the Pacific Northwest Bibliographic Center by Currier and Taylor, and from a study of network capabilities in the state of Washington by Reynolds. In these studies of interlibrary loan requests from all types of libraries within a state or region, from 51 percent to 63 percent of the requests came from public and state libraries..$^{10}$ The justification for combining state library requests with those from public libraries is that state libraries have most often served as resource libraries for the public libraries in the state. The evidence leans toward ranking public libraries, public library systems, and state libraries as the heaviest borrowers. Academic and special libraries initiate less than half of the requests, when interlibrary loan activity among all types of libraries is considered.

What types of libraries are most frequently the recipients of requests? It 
has long been assumed that a handful of large research libraries bears the greatest part of the burden of supplying items requested on interlibrary loan, and Thomson's data show, in fact, that the forty-three largest libraries (less than 6 percent of the academic libraries) account for more than 80 percent of the total number of items lent. ${ }^{11}$ Palmour's data indicate that more than 75 percent of requests are addressed to the 113 academic libraries with collections over 500,000 volumes. ${ }^{12}$ But it must be noted again that both studies were restricted to academic libraries. When all types of libraries are considered, local library systems, large public libraries, and state libraries are seen to receive a large share of the interlibrary loan requests, ranging from 35 percent to almost 90 percent of those originating within the state or interstate region. ${ }^{13}$ These data are obtained from studies of states and regions having centralized interlibrary loan systems and may not be typical for areas not having such systems.

Both Thomson and Palmour show that the geography of loan is directly related to the size of library. ${ }^{14}$ The largest academic libraries lend more outof-state and to more distant states than do smaller libraries. They also borrow more from out-of-state and from more distant states. Comparable data are not available for public libraries and other types, but it has been shown in general that borrowing by public libraries is much more localized than that by academic, special, and medical libraries regardless of size of borrowing library. ${ }^{15}$

\section{Kinds of Material Requested}

What kind of material is most often requested on interlibrary loan? Here will be considered the form, the subject, the recency, and the language of material. In large part these characteristics are affected by the restrictions of the National Interlibrary Loan Code, which frowns on borrowing items which are easily and inexpensively acquired, items requested by undergraduate students, materials wanted for recreational rather than informational or research needs, and materials needed frequently enough by the borrowing library that they should be part of its collections. These restrictions are not always observed scrupulously, and they are generally ignored in intrastate and intraregional borrowing where interlibrary loan has been organized in a system, as in New York, Illinois, the Rocky Mountain region, and the Pacific Northwest region. But their effect is noted in the statistics gathered on a national scale. When requests are classified by form of material (Table 1), it can be seen that half or less of requests to academic libraries are for books, but books predominate in the requests to systems involving public and other kinds of libraries. ${ }^{16}$ The same difference is noted in the first report of MINITEX (Minnesota Interlibrary Teletype Experiment). ${ }^{17}$

TABLE 1

Form of Materlat Requested

\begin{tabular}{lllcccc}
\hline \hline \multicolumn{1}{c}{ Study } & Book & Serial & $\begin{array}{c}\text { Dissertation/ } \\
\text { Thesis }\end{array}$ & Other & Unknown & Total \\
\hline Thomson & $50 \%$ & $34 \%$ & $9 \%$ & $7 \%$ & & $100 \%$ \\
Palmour & 48 & 34 & 6 & 12 & & 100 \\
NYSILL & 62 & 11 & & $24^{\circ}$ & $14 \%$ & 100 \\
Currier & 84 & 11 & 3 & 2 & 100 \\
\hline
\end{tabular}

- In the NYSILL study, 24 percent of the requests were for "nonbooks." This includes serials, theses, AV, and other forms. 
TABLE 2

SubJect OF Requested Material

\begin{tabular}{lcccccc}
\hline \hline \multicolumn{1}{c}{ Study } & Humanities & $\begin{array}{c}\text { Social } \\
\text { Science }\end{array}$ & $\begin{array}{c}\text { Science/ } \\
\text { Technology }\end{array}$ & Other & Unknown & Total \\
\hline Thomson & $26 \%$ & $23 \%$ & $15 \%$ & $15 \%$ & $21 \%$ & $100 \%$ \\
Palmour & 27 & 21 & 40 & 12 & 13 & 100 \\
NYSILL & 24 & 16 & 35 & 12 & 13 & 100 \\
Currier & 38 & 17 & 25 & 12 & 8 & 100 \\
$\begin{array}{l}\text { Reynolds } \\
\quad \text { U. of Washington }\end{array}$ & 42 & 18 & 40 & & & 100 \\
$\quad \begin{array}{l}\text { Washington } \\
\quad \text { State Library }\end{array}$ & 41 & 21 & 28 & 10 & & \\
\hline
\end{tabular}

In the division of requests according to subject (Table 2), no significant pattern can be seen either in the frequency of demand of one broad subject field over another or in the subject needs of one type of library over another. ${ }^{18}$ Thomson, who classified requests according to the instructional department of the requestor, used the rubric "other" for professional schools; in other studies "other" refers to fiction, biography, and categories not classified by subject. Reynolds compared requests received by the University of Washington Library with those received by the Washington State Library, where again the differences are minimal except in the categories "science/technology" and "other."

In the analysis of requests by recency of publication, a strong pattern is seen, but it is similar for all types of libraries. ${ }^{19}$ In Table 3 , it can be seen that approximately 20 percent of the requests are for items published within the previous three years, and more than half are for items published within the previous ten years. Currier's data, which could not be fitted to this table, show the same degree of recency of the requested items.

Another characteristic of the titles requested on interlibrary loan noted in most of the studies is the language of the material. All studies found a preponderance of the material to be in English, ranging from 67 percent to 99 percent, with a median of 86 percent. Palmour broke language down further to note the subject and format most associated with language. Humanities serials were most often in a language other than English, and monographs in the humanities next most often in a foreign language. Social science and pure/ applied science materials have nearly the same percents in English; their serials are least likely to be in English (84 89 percent) and theses most likely (97100 percent). Frequencies of other languages are shown by Palmour to be: German and French, each 4 percent; Spanish, 2 percent; Italian and Russian, each 1 percent. ${ }^{20}$

TABLE 3

Cumulated Percent by Recency of Material

\begin{tabular}{lcccc}
\hline \hline \multicolumn{1}{c}{ Study } & Last 3 Years & Last 10 Years & Last 70 Years & Unknown \\
\hline Palmour & $21 \%$ & $58 \%$ & $92 \%$ & $2 \%$ \\
Taylor & 17 & 49 & 94 & \\
Reynolds & 19 & 54 & $?$ \\
$\quad$ U. of Washington & 25 & 70 & 99 & \\
$\quad$ Washington & State Library & & & \\
\hline
\end{tabular}


TABLE 4

OUTCOME OF REQUESTS

\begin{tabular}{lccccc}
\hline \hline \multicolumn{1}{c}{ Study } & Filled & Not Owned & Not Available & Noncirculating & Total Unfilled \\
\hline Thomson & $64 \%$ & $15 \%$ & $10 \%$ & $11 \%$ & $36 \%$ \\
Palmour & 71 & 15 & 9 & 5 & 29 \\
New York State & 83 & & & & 17 \\
\hline
\end{tabular}

\section{The Success Rate}

Estimates of the average rate of filling requests successfully are difficult to obtain from previous studies because most data are based on success or failure at the first library to which the request was sent, or on a "single pass," and do not reflect the eventual success after several passes. The percent of requests filled on the first pass is seen from Table 4 to be almost two-thirds or more. ${ }^{21}$ Those not supplied are most often not owned by the library from which they were first sought. Less often they are not available: lost, in use, on reserve, in the bindery, or a non-owned volume of a serial title which the library does hold. "Noncirculating" means that because of poor condition or rarity the library does not permit its loan outside the building. Only 6.6 percent of the items requested in the Thomson study were not available because they were lost, in use at the time, on reserve, or at the bindery. In the Palmour survey, only 2 percent of the requested items were in use at the time. These findings are important in showing that lending an item apparently does not disrupt service at the lending library as much as is sometimes assumed.

Thomson showed (Table 5) that most success is met in obtaining a microform or a Master's essay, least in obtaining a government document or a technical report. ${ }^{22}$ "Not owned" is the most frequent cause of failure to supply technical reports, government documents, and books. "Noncirculating" is a frequent reason for not supplying dissertations and, to a lesser extent, newspapers and serials. Newspapers and serials are the forms most often reported "not available," and this probably means that the library has the title but not the issue requested.

The success rate reported for an interlibrary loan network or a bibliographic center is of interest. Table 4 reported success rates based on the average of reports from individual libraries. NYSILL reported 47 percent of the requests filled at the headquarters in New York State Library and an additional 17 percent filled by one of the referral libraries (e.g., Cornell University, Columbia University) to which they had been sent when not available at New

TABLE 5

Outcome of Requests for Material in Different Formats

\begin{tabular}{lccccc}
\hline \hline Format & Filled & Not Available & Noncirculating & Not Owned & Total Unfilled \\
\hline Book & $64 \%$ & $10 \%$ & $8 \%$ & $18 \%$ & $36 \%$ \\
Serial & 63 & 12 & 16 & 9 & 37 \\
Government document & 59 & 11 & 9 & 21 & 41 \\
Microform & 85 & 0 & 6 & 9 & 15 \\
Newspaper & 69 & 11 & 13 & 7 & 31 \\
Technical report & 61 & 4 & 4 & 31 & 39 \\
Dissertation & 63 & 5 & 25 & 7 & 37 \\
Master's essay & 82 & 4 & 9 & 5 & 18 \\
\hline
\end{tabular}


York State Library. ${ }^{23}$ This statistic seems to compare unfavorably with the 83 percent success rate reported in Table 4 and is deceptive. The 83 percent rate is the one reported on a questionnaire by libraries of New York State for having their requests filled from any source. The rate of 64 percent refers to requests which could not be filled in the local public library system or the local $R \& R$ system and which were subsequently sent to NYSILL. These requests included many for fiction, recent books, or other categories not usually honored in interlibrary loan; requests of these types were not referred beyond the New York State Library, if they could not be filled there, but were returned to the requesting library. If those requests (22 percent) were eliminated from the statistic, NYSILL's success rate would approach 86 percent.

Several statistics have been reported for success in finding requested items by referral to the Pacific Northwest Bibliographic Center (PNBC). ${ }^{24}$ Currier reported locations found for 76 percent of a sample of items requested through PNBC in 1969. Two years later, Taylor studied a sample of requests sent to PNBC and reported 74 percent located in the region and another 9 percent located outside the region. "Locations," however, do not take into account items lost, no longer owned, in use, or otherwise not supplied by the library which is supposed to have them.

\section{TIME REQUIRED}

Different studies of the time required to fill a request are difficult to compare because of the variation in the parts of the interlibrary loan process taken into account. Some studies report on the total elapsed time from sending the request out from the borrowing library to receipt of the material. Only the single pass is usually counted. Some studies have considered only the "cycle-time," or the amount of time the request is in the lending library until the material is shipped out or a not-filled report is sent back to the borrowing library. In the study of academic libraries made by Palmour and others at Westat Research, Inc., for the Association of Research Libraries, the material requested was received in the borrowing library within five days after the request had been sent out in nearly 20 percent of the successfully completed transactions and within ten days in 50 percent of the cases. This study did not include requests that could not be filled. Palmour also shows that material supplied in photocopy requires less total time than material supplied in original form and that material in science and technology is supplied faster (52 percent within ten days) than that in the humanities and social sciences ( 46 percent within ten days). ${ }^{25}$

The average time for NYSILL to supply requested material to the borrowing library or to report inability to fill the request was sixteen days when New York State Library could supply, twentysix days when the request had to be sent to one "referral" library, and thirty days when it had to be forwarded to one, and then to a second referral library. But these statistics also included an average seven days spent in trying to find the item locally and then preparing a request to NYSILL for unfound items. ${ }^{26}$ Taylor showed that the mean time required for a library to send a request to the Pacific Northwest Bibliographic Center, for PNBC to locate the item in a member library, and for the item to reach the borrowing library was. twenty days. ${ }^{27}$ If the initial step in the procedure, searching locally and sending a request to the network, is eliminated in order to make the studies comparable, the mean time found by Taylor is sixteen days and that for NYSILL is eighteen days.

\section{Cost per Transaction}

Studies of the cost per transaction are 
not only few but also even more subject to local circumstances than are statistics of elapsed time. One of the primary purposes of the study by Palmour and colleagues was to determine the average cost per transaction. This study was very carefully made, but it is restricted to the costs of lending or borrowing by large academic libraries, those with collections of over 500,000 volumes. For the 113 academic libraries of this size in the United States, an estimate was made of the total annual cost of interlibrary loan based on detailed records supplied by 12 , selected randomly. ${ }^{28}$ Total costs were based on data for direct labor costs and fringe benefit costs of personnel, postage, supplies, communication, and any other costs of interlibrary loan. An overhead of 50 percent of the direct labor cost was added. When this estimate was divided by the total number of completed interlibrary loan transactions, both borrowing and lending transactions, an estimate of $\$ 6.39$ per transaction was derived. Data were also available dividing direct labor costs between borrowing and lending activities. These provided the base for a separate estimate of the annual costs of borrowing and of lending by the 113 large libraries. When these were divided by the total number of completed borrowing transactions (titles) and completed lending transactions (titles), the cost per borrowing transaction was estimated at $\$ 7.61$, and the cost per lending transaction at $\$ 5.82$. A difficulty with these estimates is that the total amount spent by the institutions on borrowing is divided by the number of only those requests which were filled, and similarly for lending costs. But the latter were further analyzed to produce an estimated cost per filled lending transaction, $\$ 4.60$, and another per unfilled lending transaction, \$2.12. These were deemed important because large libraries may wish to consider an adequate fee per transaction to offset its costs. Within the limits set, these are considered by the writer to be the most sound estimates of interlibrary loan costs made to date.

The volume, characteristics, outcome, and cost of interlibrary loan reported here are data from studies made during the past eight years, most during the past four years. Volume might increase dramatically in the near future, as service is extended to users and for purposes not previously recognized as suitable for interlibrary loan. This experience is already seen in New York and Illinois. The success in filling requests may well improve, and both speed and cost decrease in the near future, as the results of several studies and programs recently completed or undertaken by the Association of Research Libraries and the National Commission on Libraries and Information Science (NCLIS) are implemented. ${ }^{29}$ The association and NCLIS have wisely recognized the importance of interlibrary loan not only in research and study but also in making the nation's library resources available to readers everywhere.

\section{REFERENCES}

1. Rolland E. Stevens, A Feasibility Study of Centralized and Regionalized Interlibrary Loan Centers (Washington, D.C.: Association of Research Libraries, 1973); also issued as ERIC document ED 076206.

2. Sarah K. Thomson, Interlibrary Loan Involving Academic Libraries (ACRL Monograph, no.32 [Chicago: American Library Assn., 1970]), is an abridgement of the dissertation.
3. A Study of the Characteristics, Costs, and Magnitude of Interlibrary Loans in Academic Libraries, comp. by Vernon E. Palmour and others, prepared for the Association of Research Libraries by Westat Research, Inc. (Westport, Conn.: Greenwood Pub. Co., 1972).

4. Interlibrary Loan in New York State (New York: Nelson Associates, Inc., 1969).

5. Thomson, Interlibrary Loan, p.1.

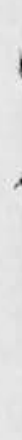


6. Study of the Characteristics, p.51.

7. Interlibrary Loan in New York State, p.3032.

8. Thomson, Interlibrary Loan, p.7; Study of the Characteristics, p.36.

9. Interlibrary Loan in New York State, p.34.

10. Genevieve Casey, The Future Role and Financial Structure of the Bibliographic Center for Research, Rocky Mountain Region (Detroit: Wayne State University, Office of Urban Library Research, 1969), p.108; Lura G. Currier, Sharing Resources in the Pacific Northwest: A Study of PNBC and Interlibrary Loan (Olympia, Wash.: Washington State Library, 1969), p.56; David W. Taylor and others, An Operations Research Study of the Pacific Northwest Bibliographic Center (Washington, D.C.: U.S. Office of Education, 1972), p.21; Maryan E. Reynolds, A Study of Library Network Alternatives for the State of Washington (Olympia, Wash.: Washington State Library, 1970), p.7.

11. Thomson, Interlibrary Loan, p.5-6.

12. Study of the Characteristics, p.37.

13. Interlibrary Loan in New York State, p.31; Currier, Sharing Resources, p.59; Taylor, Operations Research Study, p.39; Reynolds, Study of Library Network Alternatives, p.15.

14. Thomson, Interlibrary Loan, p.7-9; Study of the Characteristics, p. $35-36$.

15. Study of the Characteristics, p.36; Interlibrary Loan in New York State, p. 32 .

16. Thomson, Interlibrary Loan, p.26; Study of the Characteristics, p.42; Interlibrary Loan in New York State, p.103; Currier, Sharing Resources, p.60, 67.

17. MINITEX (Minnesota Interlibrary Teletype Experiment) 1969-1970: A Report on a Pilot Demonstration Project (Minneapolis: University of Minnesota Libraries, $1970)$, p.6.

18. Thomson, Interlibrary Loan, p.12; Study of the Characteristics, p.39; Interlibrary Loan in New York State, p.82; Currier, Sharing Resources, p.62, 67; Reynolds, Study of Library Network Alternatives, p.10.
19. Study of the Characteristics, p.39; Taylor, Operations Research Study, p.25; Reynolds, Study of Library Network Alternatives, p.9; Currier, Sharing Resources, p.60, 67.

20. Thomson, Interlibrary Loan, p.31; Study of the Characteristics, p.41-42; Interlibrary Loan in New York State, p.103; Currier, Sharing Resources, p.60, 67.

21. Thomson, Interlibrary Loan, p.64-65; Study of the Characteristics, p. 43, 46; Interlibrary Loan in New York State, p.27.

22. Thomson, Interlibrary Loan, p.71.

23. Interlibrary Loan in New York State, p.72.

24. Currier, Sharing Resources, p.71; Taylor, Operations Research Study, p.44.

25. Study of the Characteristics, p.47-48.

26. Interlibrary Loan in New York State, p.121-22.

27. Taylor, Operations Research Study, p.22, 41,45 .

28. Study of the Characteristics, p.13ff.

29. A Study of the Characteristics, Costs, and Magnitude of Interlibrary Loans in Academic Libraries, comp. by Vernon E. Palmour and others, prepared for the Association of Research Libraries by Westat Research, Inc. (Westport, Conn.: Greenwood Pub. Co., 1972); "A Feasibility Study of a System for Interlibrary Communication," by Becker \& Hayes for the Association of Research Libraries; "An Improved Interlibrary Loan System: (1) Methods of Financing Interlibrary Loan Services and (2) Design of a National Periodical Resources Center," by Westat Research, Inc., for the Association of Research Libraries; A Feasibility Study of Centralized and Regionalized Interlibrary Loan Centers, prepared by Rolland E. Stevens, submitted by the Association of Research Libraries to the National Commission on Libraries and Information Science (Washington, D.C.: Association of Research Libraries, 1973); "Regional Resources Centers and Bibliographic Centers in a National Network," by Westat Research, Inc., for the National Commission on Libraries and Information Science. 